\title{
ELECTROPHORETIC DETECTION OF MULTIPLE FORMS OF TRYPSIN-LIKE ACTIVITY IN SPERMATOZOA OF THE DOMESTIC FOWL
}

\author{
JENNY J. L. HO AND STANLEY MEIZEL \\ Department of Human Anatomy, School of Medicine, \\ University of California, Davis, California 95616
}

(Received 24th April 1970)

Buruiana (1956) reported the presence of trypsin activity in the spermatozoa of several species, including the cock. Recently Stambaugh \& Buckley (1969) demonstrated that the trypsin-like enzymatic activity of rabbit sperm acrosomes could remove the zona pellucida of rabbit ova.

The present study is concerned with the electrophoretic detection of multiple forms of trypsin-like enzymatic activity present in ejaculated spermatozoa of the domestic fowl, Gallus domesticus.

Single-combed White Leghorn and Black Australorp cock semen was collected by abdominal massage, pooled, diluted with an equal volume of phosphate buffer (Wilcox, 1958), and centrifuged at $1200 \mathrm{~g}$ for $10 \mathrm{~min}$. The sperm deposit was washed three times with phosphate buffer, re-suspended in an equal volume of water containing glass beads and sonicated for $10 \mathrm{~min}$ with a model 185D sonifier (Heat Systems, Inc.) at an output setting of seven. The sonicated suspension was centrifuged at $48,000 \mathrm{~g}$ for $1 \mathrm{hr}$.

Electrophoresis of $48,000 \mathrm{~g}$ supernatants and seminal plasma was performed with the Ortec Model 4200 flat-bed acrylamide electrophoresis system and Ortec Model 4100 pulsed constant power supply (Ortec, Inc.). Protein concentrations were determined by the method of Lowry, Rosebrough, Farr \& Randall (1951). The technique of gradient gel preparation was similar to that described by Allen (1969). The gel consisted of successive layers of $4.5 \%, 6 \%$ and $8 \%$ acrylamide made up in $0.375 \mathrm{~m}$-tris-sulphate buffer, $\mathrm{pH}$ 9. The upper and lower tank buffer was $0.0625 \mathrm{M}$-tris-borate, $\mathrm{pH}$ 9. Electrophoresis of $1.5 \mathrm{mg}$ of protein was carried out for a total of $2 \frac{1}{2} \mathrm{hr}$ at $4^{\circ} \mathrm{C}$. The pulse rates utilized were 75 pulses/sec (pps) for $5 \mathrm{~min}, 150 \mathrm{pps}$ for $75 \mathrm{~min}$ and $225 \mathrm{pps}$ for the remainder of the $2 \frac{1}{2} \mathrm{hr}$.

After electrophoresis, gels were incubated twice for $20 \mathrm{~min}$ at room temperature in $0.1 \mathrm{M}$-succinic acid-tris buffer, $\mathrm{pH} 6$, containing $1 \mathrm{mg} / \mathrm{ml}$ of Fast Blue Salt B (Matheson, Goleman and Bell Chemicals) and $0.3 \mathrm{mg} / \mathrm{ml}$ of one of the following naphthylamide substrates (Fox Chemical Co.): $\alpha$-benzoyl-D,Larginine- $\beta$-naphthylamide hydrochloride (BANA), L-lysyl- $\beta$-naphthylamide carbonate (L-Lys- $\beta$-NA), L-arginyl- $\beta$-naphthylamide hydrochloride (L-Arg- $\beta$ NA), L-lysyl-L-lysine- $\beta$-naphthylamide carbonate (L-Lys-Lys- $\beta$-NA) or $\mathcal{N}$ - 
carbobenzoxy-L-arginine- $\beta$-naphthylamide hydrochloride (Cbz-L-Arg- $\beta$-NA). Stock substrates were solubilized $(4 \mathrm{mg} / \mathrm{ml})$ in dimethylformamide or 0.001 $\mathrm{N}-\mathrm{HCl}$ plus dimethylformamide.

Enzymatic activity was detected on the gel by observing the formation of the orange-red colour produced by the coupling of the diazonium salt, Fast Blue Salt B with $\beta$-naphthylamine, a product of the enzymatic hydrolysis of the naphthylamide substrates.

The enzymatic hydrolysis of BANA, carried out in the presence of diazonium salts, has been previously utilized in colorimetric assays (Riedel \& Wünsch, 1959), histochemical localization (Hopsu \& Glenner, 1963) and the electrophoretic detection (Riekkinen, Ekfors \& Hopsu, 1966) of tissue trypsin-like activity. In the present paper, using BANA as the substrate, three distinct zones of sperm enzymatic activity $(a, b, c$, Plate 1$)$ were detected towards the anode in the $8 \%$ gel, while sperm enzymatic activity which had no electrophoretic mobility was localized at the origin (d, Plate I). No activity was detected after the electrophoresis of seminal plasma. The same four zones of enzymatic activity were detected after electrophoresis of frozen and fresh sperm preparations obtained from five different pooled semen samples and from semen of each strain treated separately. In all the sperm samples studied, zone $\mathrm{c}$ was the most intensely stained. Incubation of gels before staining for $20 \mathrm{~min}$ in buffer at $\mathrm{pH} 6$ containing $1 \mathrm{mg} / \mathrm{ml}$ soybean, lima bean or ovomucoid trypsin inhibitors (Nutritional Biochemical Go.) completely inhibited the appearance of enzymatic activity during the first $20 \mathrm{~min}$ of staining, but not during the second $20 \mathrm{~min}$. When trypsin inhibitors were also present in the staining solutions, no enzymatic activity was detected during the first or second incubation with staining solution. Incubation of gels with crystallized bovine albumin before and during staining did not inhibit enzymatic activity. Trypsin inhibitors purified from natural sources can contain inhibitors of chymotrypsin, but chymotrypsin does not hydrolyse BANA (Riedel \& Wünsch, 1959).

The same four zones of activity, which were detected when using BANA as the substrate, were also observed when Gbz-L-Arg- $\beta$-NA was the substrate. As in the case of BANA, these four zones were also completely inhibited by soybean trypsin inhibitor. Seminal plasma did not hydrolyse Cbz-L-Arg- $\beta$-NA.

No hydrolysis of L-Lys-Lys- $\beta$-NA either by spermatozoa or seminal plasma was detected on the gels, but both hydrolysed L-Arg- $\beta$-NA and L-Lys- $\beta$-NA. Hydrolysis of these substrates occurred only at the gel origin. The seminal plasma activity was much stronger than that of the spermatozoa. Soybean trypsin inhibitor did not inhibit seminal plasma and sperm hydrolysis of L-Lys- $\beta$-NA or L-Arg- $\beta$-NA. Thus, this enzymatic activity was different from that which hydrolysed BANA and Cbz-L-Arg- $\beta$-NA at zone $d$. The zones of activity seen in Plate 1 may represent isozymes of trypsin-like activity. They all hydrolysed BANA and Cbz-L-Arg- $\beta$-NA, did not hydrolyse three other substrates and were inhibited by three different trypsin inhibitors. The term, 'isozymes', describes multiple molecular forms of enzymes within an organism which can be resolved by a variety of techniques and which can catalyse the same reactions (Markert, 1968). It is a broad operational definition rather than a description of a specific molecular relationship. Isozymes may include 
PLATE 1

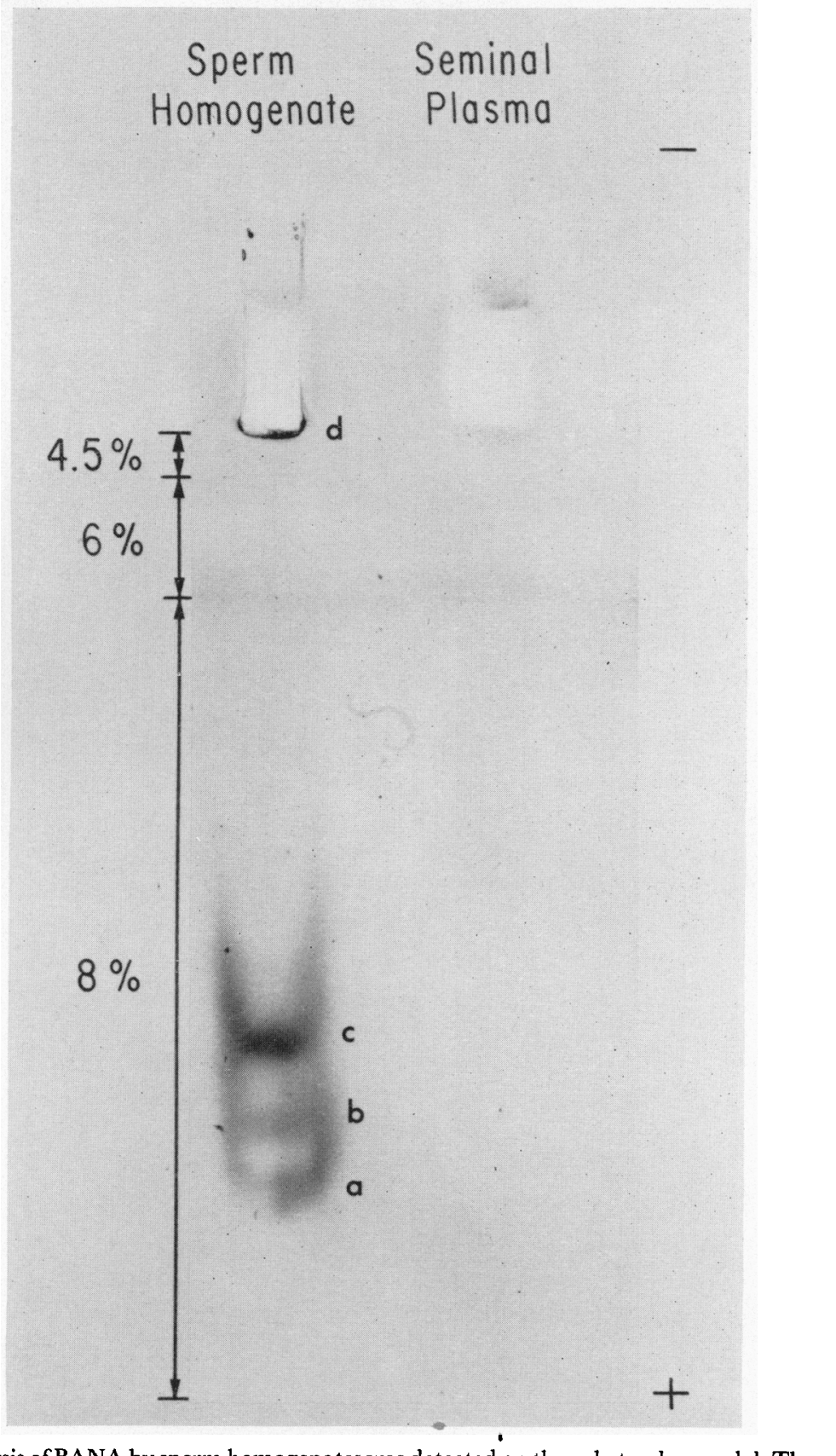

Hydrolysis of BANA by sperm homogenates was detected on the gel at a, b, c and d. There was no hydrolysis of BANA by seminal plasma.

(Facing p. 178) 
proteins which differ in primary structure, size, conformation, or in other ways (Markert \& Whitt, 1968). Further studies are being undertaken in order to elucidate the nature of the multiple forms of trypsin-like activity detectable in cock spermatozoa.

This work was supported in part by an NIH Grant No. HD 03549 to one of us (S.M.); and in part by a Health Sciences Advancement Award (USPHS No. RR 06138) predoctoral fellowship to one of us (J.H.).

The authors wish to express their gratitude to Dr Frank X. Ogasawara and Mr Lester Fuqua, Department of Avian Sciences, University of California, Davis, for their generous help in collecting semen.

\section{REFERENCES}

AlLEN, R. C. (1969) Ortec instruction manual, Model 4200 electrophoresis system. Oak Ridge, Tennessee.

Buruiana, L. M. (1956) Sur l'activité hyaluronidasique et trypsinique de sperme. Naturwissenschaften, $43,523$.

Hopsu, V. K. \& Glenner, G. G. (1963) A histochemical enzyme kinetic system applied to the trypsinlike amidase and esterase activity in human mast cells. 7. Cell Biol. 17, 503 .

Lowry, O. H., Rosebrough, N. J., FARR, A. L. \& Randall, R. J. (1951). Protein measurement with the Folin phenol reagent. F. biol. Chem. 193, 265.

Markert, C. L. (1968) The molecular basis for isozymes. Ann. N.Y. Acad. Sci. 151, 14.

Markert, C. L. \& WhitT, G. S. (1968) Molecular varieties of isozymes. Experientia, 24, 977.

RIEDEL, A. \& WüNSGH, E. (1959) $\mathcal{N}^{\alpha}$-Benzoyl-arginin- $\beta$-naphthylamid als Substrat zur quantitativen kolorimetrischen Bestimmung von Trypsin. Hoppe-Seyler's Z. physiol. Chem. 316, 61.

Riekkinen, P. J., Ekfors, T. O. \& Hopsu, V. K. (1966) Purification and characteristics of an alkaline protease from rat-submandibular gland. Biochim. biophys. Acta, 118, 604 .

Stambaugh, R. \& Buckley, J. (1969) Identification and sub-cellular localization of the enzymes effecting penetration of the zona pellucida by rabbit spermatozoa. F. Reprod. Fert. 19, 423.

WiLcox, F. H. (1958) The effect of dilution and concentration of chicken semen on fertility. Poultry Sci. $37,1357$. 